\title{
O ensino de filosofia nas perspectivas inter e transdisciplinar: uma análise da problemática ontológica
}

Gilson Malta da Silva

Universidade Federal de São João del-Rei (Brasil)

\section{Resumo}

Este artigo tem por objetivo analisar as características de um ensino de filosofia, investigado numa pesquisa de mestrado. Buscou-se averiguar o seguinte problema: como um ensino de filosofia, proposto nas perspectivas inter e transdisciplinar, estava sendo organizado numa determinada unidade educacional? Assim, realizou-se uma pesquisa descritiva de natureza qualitativa, tendo por referenciais teóricos Edgar Morin e Basarab Nicolescu. A metodologia foi composta por investigação teórica e incursão a campo. A primeira constituiu-se de pesquisa bibliográfica e análise documental. A segunda consistiu-se em observar a organização do ensino em sala de aula. Além disso, utilizou-se para analisar os dados, a técnica de análise de conteúdo. As questões discutidas nesse artigo referem-se ao conjunto das aulas nas quais foi abordada a problemática ontológica, ou seja, temas, problemas, conceitos relacionados à organização, às percepções e às significações sobre o Real, Realidade ou Natureza. Por fim, a análise das características do ensino investigado não permite considerá-lo um ensino de filosofia inter ou transdisciplinar, mas uma vivência de multidisciplinaridade escolar "modesta"; conquanto mais versátil que o conjunto das aulas sobre os conteúdos epistemológicos, divulgados no primeiro artigo.

Palavras-chave: Ensino de filosofia. Interdisciplinaridade. Transdisciplinaridade.

\section{The teaching of philosophy in the inter and transdisciplinary perspecti- ves: an analysis of the ontological problem}

\section{Abstract}

This article aims to analyze the characteristics of a philosophy teaching that was investigated in a master's degree research. We have sought to ascertain the following problem: how a teaching of philosophy, proposed in the inter and transdisciplinary perspectives, was being organized in an educational unit? Thus, a descriptive research of qualitative nature was carried out, using theoretical references by Edgar Morin and Basarab Nicolescu. The methodology was composed by theoretical investigation and field incursion. The first consisted of bibliographical research and documentary analysis. The latter consisted of observing the organization of teaching in the classroom. In addition, we have used the technique of content analysis to analyze the data. The questions discussed in this article refer to the set of classes in which the ontological problematic was approached, that is, themes, problems, concepts related to organization, perceptions and meanings about the Real, Reality or Nature. Finally, the analysis of the characteristics of the teaching investigated does not allow it to be consider a teaching of inter or transdisciplinary 
ensino de filosofia nas perspectivas inter e transdisciplinar: uma análise da problemática ontológica

philosophy, but an experience of "modest" school multidisciplinarity; although more versatile than the set of classes on the epistemological contents disclosed in the first article.

Keywords: Teaching philosophy. Interdisciplinarity. Transdisciplinarity.

\section{La enseñanza de filosofía en las perspectivas inter y transdisciplinar: un análisis de la problemática ontológica}

\section{Resumen}

Este artículo tiene por objetivo analizar las características de una enseñanza de filosofía que fue investigada em una investigación de maestría. Se buscó averiguar el siguiente problema: como una enseñanza de filosofía, propuesta en las perspectivas inter y transdisciplinar, estaba siendo organizada en una unidad educativa? Así, se realizó una investigación descriptiva de naturaleza cualitativa teniendo por referenciales teóricos Edgar Morin y Basarab Nicolescu. La metodología fue compuesta por investigación teórica e incursión a campo. La primera se constituyó de investigación bibliográfica y análisis documental. La segunda consistió en observar la organización de la enseñanza en la clase. Además, se utilizó para analizar los datos, la técnica de análisis de contenido. Las cuestiones discutidas en este artículo se refieren al conjunto de las clases en las que se abordó la problemática ontológica, es decir, temas, problemas, conceptos relacionados a la organización, a las percepciones ya las significaciones sobre el Real, Realidad o Naturaleza. Por último, el análisis de las características de la enseñanza investigada no permite considerarlo como una enseñanza de filosofía inter o transdisciplinar, sino una vivencia de multidisciplinaridad escolar "modesta"; si bien más versátil que el conjunto de las clases sobre los contenidos epistemológicos, divulgados en el primer artículo.

Palabras clave: Enseñanza de filosofía. Interdisciplinariedad. Transdisciplinariedad.

\section{Considerações iniciais}

Este é o segundo artigo de uma sequência que visa analisar as características de um ensino de filosofia, investigado numa pesquisa de mestrado. No primeiro artigo', analisou-se o debate das questões referentes ao conjunto das aulas tendo sido abordada a problemática epistemológica, ou seja, temas, problemas conceitos concernentes à construção do conhecimento, distinção entre conhecimentos científicos e filosóficos, o pensamento, as perguntas, os problemas e os saberes. As questões discutidas, neste segundo artigo, referem-se ao conjunto das aulas tendo sido abordada a problemática ontológica, ou seja, temas, problemas, conceitos relacionados à organização, às percepções 
e às significações sobre o Real bem como os conhecimentos que se podem elaborar sobre a Natureza ou Realidade.

$\bigcirc$ contexto em que essa pesquisa se insere é o da Reforma da Educação Básica. A delimitação temporal-institucional, assumida para a pesquisa, foi o período entre 1996 e 2013 . Todavia, como o primeiro artigo sobre a pesquisa foi publicado em dezembro de 2017, enunciaram-se em nota as alterações na Lei de Diretrizes e Bases da Educação Nacional (LDB), Artigo 35-A, feitas pela Lei 13.415, de 16 de fevereiro de 2017, a fim de esclarecer que, no tocante à reorganização curricular em Áreas do Conhecimento, houve, apenas, uma pequena mudança de nomenclatura.

Pelo exposto, pode-se afirmar que, um dos maiores desafios da referida reforma educacional, desde as primeiras Diretrizes Curriculares de 1998, tem sido a concretização nas escolas da nova perspectiva curricular, particularmente, do ensino médio. A mencionada modificação consiste em reorganizar o currículo escolar em "áreas do conhecimento" com o propósito de viabilizar a seleção dos conteúdos disciplinares mais significativos e, assim, concretizar uma proposta educacional baseada na metodologia de ligação dos saberes denominada "interdisciplinar" e, outra, "transdisciplinar" bem como a "contextualização2" (BRASIL, 2000, p. 7 e 17).

Por interdisciplinaridade entende-se aqui uma abordagem teóricometodológica "[...] em que a ênfase incide sobre o trabalho de integração das diferentes áreas do conhecimento, um real trabalho de cooperação e troca, aberto ao diálogo e ao planejamento" (BRASIL, 2013, p. 28). Outrossim, a transdisciplinaridade consiste na [...] troca dinâmica entre as ciências "exatas", as ciências "humanas", a arte e a tradição (COLÓQUIO DE VENEZA, 1986, p. 1, n 3; grifo do autor).

Ademais, refere-se ao

[...] reconhecimento da existência de diferentes níveis de realidade regidos por lógicas diferentes [...] A transdisciplinaridade é complementar a aproximação disciplinar: faz emergir da confrontação das disciplinas dados novos que as articulam entre si; oferece-nos uma nova visão da natureza e da realidade [...] $\bigcirc$ ponto de sustentação da transdisciplinaridade reside na unificação semântica e operativa das acepções através e além das disciplinas (CONGRESSO DE ARRÁBIDA, 1994, p. 1 e 2; Art. $2^{\circ}, 3^{\circ}$ e $4^{\circ} \%$ 
ensino de filosofia nas perspectivas inter e transdisciplinar: uma análise da problemática ontológica

E, ainda,

[...] A transdisciplinaridade, como o prefixo "trans" o indica, diz respeito ao que está ao mesmo tempo entre as disciplinas, através das diferentes disciplinas e além de toda disciplina. [...] Os três pilares da transdisciplinaridade: os níveis de Realidade, a lógica do terceiro incluído e a complexidade determinam a metodologia da pesquisa transdisciplinar (CONGRESSO DE LOCARNO, 1997, p. 3; grifo do autor)

A respeito da pluridisciplinaridade e da multidisciplinaridade ressalta-se que: a primeira "[...] estuda um objeto de uma disciplina pelo ângulo de várias outras ao mesmo tempo" (BRASIL, 2013, p. 28). Todavia, essas disciplinas são de áreas vizinhas no domínio do conhecimento e mantêm mínimas articulações. A segunda "expressa frações do conhecimento e o hierarquiza" (BRASIL, 2013 , p. 28). Ademais, justapõem disciplinas de distintas grandes áreas do conhecimento, porém mantêm entre elas fracas interações e suas fronteiras permanecem bem definidas (WEIL, AMBRÓSIO, CREMA, 1993; NICOLESCU, 1999).

Nessa ótica, preconiza-se uma concepção transdisciplinar e matricial do currículo que deve ser organizado por eixos temáticos ou temas estruturadores e não mais pela antiga concepção de "grade" curricular com disciplinas estanques e conteúdos desarticulados (BRASIL, 2013, p. 30; grifo do autor). Atualmente ${ }^{3}$, as áreas em questão denominam-se: Linguagens e suas Tecnologias; Matemática e suas Tecnologias; Ciências da Natureza e suas Tecnologias; Ciências Humanas e Sociais Aplicadas.

Ademais, a fim de resolver essa problemática da compartimentação do conhecimento escolar, no ensino médio, a interdisciplinaridade e a contextualização foram regulamentadas, desde as primeiras Diretrizes, como princípios pedagógicos estruturadores das matrizes curriculares das unidades educacionais. Entretanto, em decorrência da persistência da citada problemática, manteve-se no documento Brasil (2013a) essa normatização.

No tocante ao ensino de filosofia, Brasil (2006) explicita que a filosofia deve ser considerada uma disciplina obrigatória no ensino médio, com seus textos próprios que exprimam sua história e identidade, visto que essa condição é indispensável para que ela contribua no debate com as outras disciplinas e nos projetos transversais. Ainda que a filosofia não seja uma ciência, 
no sentido de tradição empírica, tampouco uma arte, no sentido de criação artística, "[...] ela sempre teve conexões íntimas e duradouras com os resultados das ciências e das artes" (BRASIL, 2006, p. 22).

É nesse cenário que se insere a proposta do Colégio Nossa Senhora de Lourdes em construir um ensino de filosofia inter e transdisciplinar. $\bigcirc$ referido Colégio faz parte da rede privada de ensino e está localizado na região central do município de Lavras, no Estado de Minas Gerais. Trata-se de uma instituição de orientação católica. Em fevereiro de 2012, foi feita uma visita a esse Colégio no intuito de solicitar à diretoria uma autorização para realizar a pesquisa. Concedida a autorização, na semana seguinte, iniciaram-se as observações, respectivamente, no $1^{\circ}, 2^{\circ}$ e $3^{\circ}$ anos do ensino médio.

Quanto aos aspectos metodológicos, seguiu-se o seguinte percurso:

1) Pesquisa Bibliográfica: a) leitura exploratória: identificar as fontes bibliográficas sobre as metodologias de ligação dos saberes (M.L.S.), a reforma do ensino médio (R.E.M.) e o ensino de filosofia (E.F.) assim como definir os referenciais teóricos e as demais referência. b) leitura seletiva: delimitação do corpus bibliográfico da pesquisa para contextualizar/caracterizar as M.L.S., R.E.M., E.F., bem como aprofundar a compreensão do referencial teórico e demais referências. c) leitura analítica: ordenar, compreender, sumariar os dados/informações por fichamentos e definição das categorias analíticas, a saber: pluridisciplinaridade, multidisciplinaridade, interdisciplinaridade, e transdisciplinaridade; "balizas para o conhecimento do objeto" - o ensino de filosofia nas perspectivas inter e transdisciplinar - "nos seus aspectos gerais" (MINAYO, 2000, p. 94). d) leitura interpretativa: relacionar os argumentos abordados pelos autores com o problema de pesquisa, a saber: como estava sendo organizado um ensino de filosofia proposto nas perspectivas inter e transdisciplinar, no Colégio Nossa Senhora de Lourdes?

2) Análise Documental: a) identificar as fontes primárias, sobre as M.L.S., elaboradas nos distintos encontros internacionais, com o intuito de melhor explicitá-las. b) assinalar os documentos governamentais sobre R.E.M., e E.F., ampliando a compreensão a respeito deles e, principalmente, das relações entre o ensino de filosofia e as demais disciplinas escolares. c) conhecer os objetivos do Projeto Político-Pedagógico do mencionado Colégio, dos Planos Anuais do Curso de Filosofia dos três anos do ensino médio e quais os materiais didáticos selecionados pelo docente para realizar sua mediação. 
ensino de filosofia nas perspectivas inter e transdisciplinar: uma análise da problemática ontológica

3) Incursão a Campo: a) técnica de coleta de dados: observação não-participante. Segundo Marconi e Lakatos (2010, p. 176), "por mais que o observador não se envolva tanto nas situações observadas" e não vá para o campo com um programa rigidamente preestabelecido para a coleta de dados, "esse procedimento tem caráter sistemático", ou seja, científico; b) técnica de registro dos dados: diário de campo e, posteriores transcrições para o arquivo digital; cl período da incursão a campo: observação de 62 aulas de filosofia, nos três anos do ensino médio, durante o primeiro e o segundo semestres do ano de 2012, concluindo 30 semanas de observação; d) sujeitos participantes: docente de filosofia, discentes dos três anos do ensino médio lem torno de 75 estudantes), coordenador pedagógico (três conversas informais); e) principais fontes de informações coletadas: temas, problemas, conceitos do ensino de filosofia, abordados em sala de aula, com base em conhecimentos, alusões ou menções a conteúdos de outras disciplinas.

4) Seleção dos dados, análise das informações pertinentes, tratamento dos resultados (tabulação), inferências e interpretação: técnica para análise dos dados: análise de conteúdo. Etapas: (4.1) Pré-análise dos dados - seleção dos dados/informações que, de fato, possibilitavam investigar o objeto de 6 pesquisa; (4.2) Análise das informações pertinentes - Constituição do corpus de pesquisa com as informações mais pertinentes de acordo com o problema de pesquisa; (4.3) Codificação e categorização das informações - constituição de três categorias empíricas: Realidade, Conhecimento e Ser Humano. Com essas categorias, pretendeu-se "apreender as determinações e as especificações" manifestadas na realidade empírica (BARDIN, 1988, p. 107). Além disso, foram separadas as informações, ou seja, os temas, problemas e conceitos, debatidos nas aulas e, constituintes do corpus, para, em seguida, reagrupá-los segundo as categorias empíricas (BARDIN, 1988; MINAYO, 2000); (4.4) Tabulação dos dados - elaboração dos quadros de resultados. Esse tratamento das informações objetivou dispor os resultados da análise de tal modo que facilitasse a visualização das inter-relações entre eles e a comprovação ou refutação da hipótese conjecturada. Por fim, foram realizadas inferências interpretativas para a construção do conhecimento enunciado pelos textos descritivo-analíticos. 


\title{
Apresentação e problematização dos dados bibliográficos, documentais e de campo
}

\author{
Quadro 1 \\ Temáticas, problemas e definições
}

\begin{tabular}{|c|}
\hline Dados coletados \\
\hline Dados do campo \\
\hline 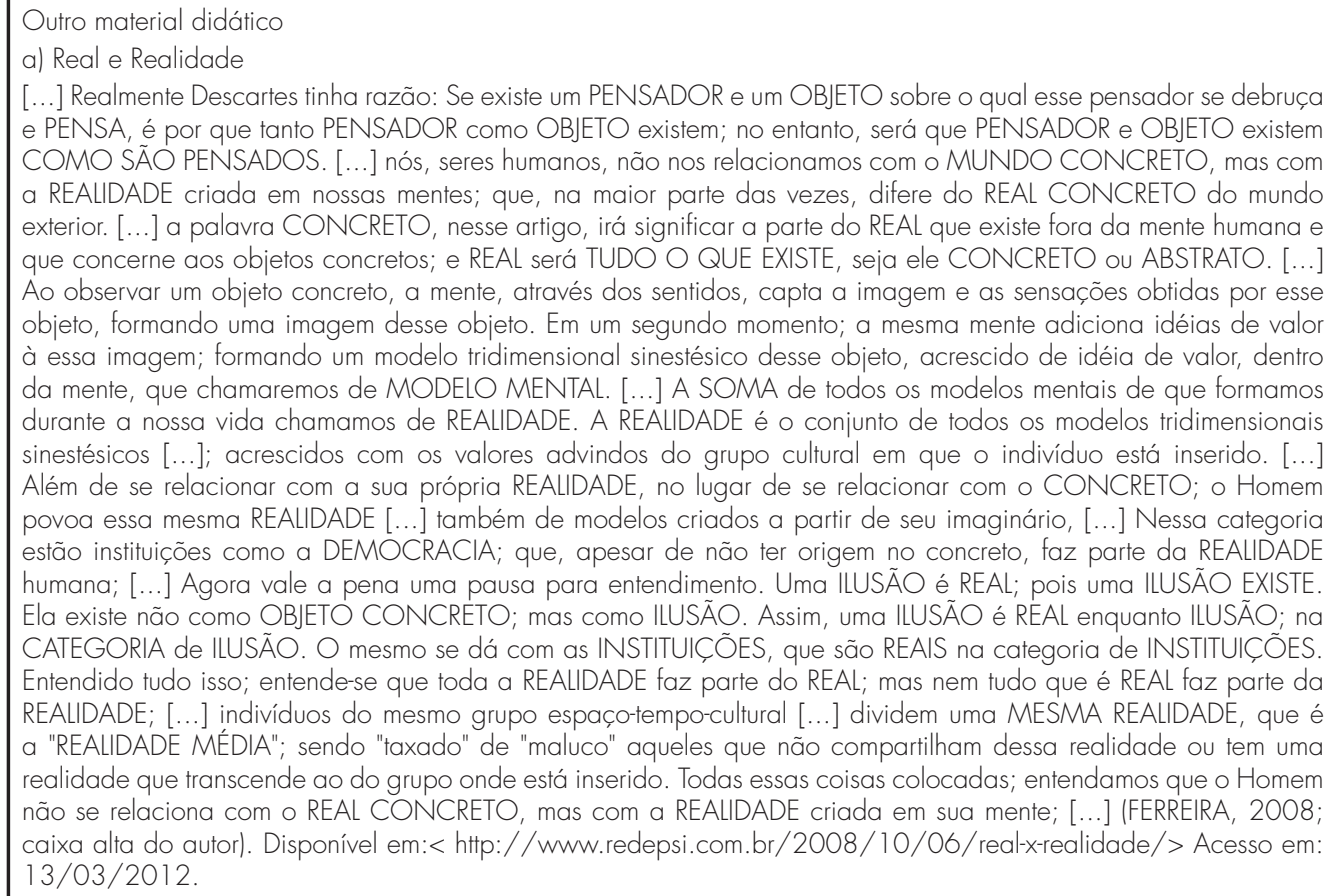 \\
\hline
\end{tabular}

Capítulo - 7: Marina (2010)

b) Introdução: humanizar a realidade

[...] A inteligência humana pode enfrentar a realidade com diferentes projetos. É importante conhecê-la; saber como é, como funciona, como prever seus comportamentos. Essa é a tarefa das ciências e da filosofia. Ambas, cada uma à sua maneira aspira conhecer a realidade. Mas a inteligência tem outros projetos, um dos quais, que também faz parte da filosofia, é "humanizar a realidade". Trata-se de dar significado às coisas, inventar os conceitos, as idéias necessárias para tornar a realidade habitável e identificável, além de conseguir que nosso mundo - o mundo pessoal e o que compartilhamos - seja compreensível e humano. Essa filosofia da vida não nos traz a mesma segurança das ciências, mas permite ao ser humano inventar conceitos ou teorias para dar significado à realidade. [...] Friedrich Hölderlin (1770 - 1843), um grande poeta alemão, escreveu um verso que vale a pena citar: "Poeticamente o homem habita a terra". [...] Significa que devemos viver criativamente, inventando modos humanos de entender a realidade, de construíla. A inteligência inventa três grandes projetos: conhecer a realidade, transfigurar a realidade esteticamente e humanizar a realidade. Descobrimos outra função da filosofia, que a distancia ainda mais da ciência. A filosofia não se resigna a ser um modo pessoal de ver o mundo e tampouco se interessa por apenas conhecer a realidade. Aspira a humanizá-la racional e justificadamente (MARINA, 2010, p. 134-135). 
Quadro 1

Temáticas, problemas e definições (cont.)

\begin{tabular}{|c|}
\hline Dados coletados \\
\hline Dados do campo (sala de aula) e Marina (2010) \\
\hline $\begin{array}{l}\text { c) A ontologia } \\
\text { A palavra "ontologia" deriva da expressão grega tou óntos logos: a ciência de tudo que há, de tudo o que existe. } \\
\text { Para definir uma ciência, devem-se indicar o objeto que ela estuda e o ponto de vista a partir do qual o estuda, } \\
\text { chamados pelos filósofos medievais, respectivamente, "objeto material" e "objeto formal" do conhecimento. Por } \\
\text { exemplo, o ser humano pode ser um objeto material da física, da química, da biologia e da história, mas cada uma } \\
\text { dessas áreas o estuda de perspectivas diferentes: como conjunto de átomos, como conjunto de moléculas, como } \\
\text { organismo vivo, como protagonista dos fatos sociais. O objeto de estudo da ontologia é o conjunto de todos os } \\
\text { seres, e seu objetivo formal é estudar, simplesmente, o que todos têm em comum: o ser. Parece que de um tema tão } \\
\text { amplo e vago não se pode dizer nada interessante, mas veremos que não é assim. De acordo com Aristóteles, deve- } \\
\text { se levar em conta que "o ser se diz de muitas maneiras". Há seres reais e seres irreias. Dom Quixote de La Mancha, } \\
\text { famosa personagem do escritor espanhol Miguel e Cervantes (1547 - 16l6), não é real, mas existe de alguma } \\
\text { maneira (MARINA, } 2010 \text {, p. } 137 \text {; aspas do autor). } \\
\text { 1. (Problemas da ontologia) } \\
\text { A ontologia propõe outros problemas no campo da física: os físicos elaboram teorias sobre a realidade para } \\
\text { explicar ou prever os fenômenos, mas falam de entidades das quais é difícil dizer se são objetos reais ou apenas } \\
\text { idéias criadas para pensar a realidade, e que são úteis para compreendê-la e manipulá-la. No campo das ciências } \\
\text { sociais, também existem problemas ontológicos: o que é povo? O que é nação? O que significa igualdade social? } \\
\text { Todos têm o mesmo direito? Em suma, há um princípio "ontológico" que sustente as afirmações e os conceitos } \\
\text { utilizados pelas ciências de forma geral? (MARINA, } 2010, \text { p. } 137 \text { ). }\end{array}$ \\
\hline $\begin{array}{l}\text { d) A passagem da ontologia à gnosiologia } \\
\text { Há dois conceitos fundamentais, duas categorias, que a ontologia deve esclarecer: real/irreal. Essas categorias vão } \\
\text { nos levar à segunda parte da metafísica: a gnosiologia. Também chamada teoria do conhecimento, a gnosiologia } \\
\text { estuda as relações entre o sujeito cognoscente e o objeto conhecido. Real: é aquilo que existe independentemente } \\
\text { do fato de alguém o estar experimentando ou conhecendo. [...] Por isso, pode impor limitações. Uma parede real se } \\
\text { diferencia de uma parede irreal porque impede a passagem. (MARINA, 2010, p. 139; negritos do autor). }\end{array}$ \\
\hline
\end{tabular}

Fonte: Pesquisa de campo e bibliográfica (2013). 


\section{Quadro 2 \\ Temáticas, problemas e definições}

\begin{tabular}{|c|}
\hline Dados coletados \\
\hline Livro didático: Marina (2010) \\
\hline $\begin{array}{l}\text { CAPÍTULO - } 3 \\
\text { a) Introdução: construir a realidade } \\
\text { [...] Não nos contentamos em conhecer, não nos basta possuir, não somos seres passivos. Nossos projetos buscam } \\
\text { conectar-se à realidade e ampliá-la. [...] Em muitas ocasiões, nos sentimos presos a realidade, sem poder agir, } \\
\text { limitados pelas contingências da vida. Felizmente, a inteligência nos diz que, dentro de certos limites - a morte é } \\
\text { um deles - a realidade não está totalmente decidida; está esperando que acabemos de defini-la. A realidade não } \\
\text { é bela nem feia, nem justa nem injusta, nem exultante nem deprimente, não há maniqueísmo. A vida é um conjunto } \\
\text { de possibilidades que devem ser construídas. Por isso, nada é definitivo, tudo está por vir. As coisas adquirem } \\
\text { propriedades novas quando vamos em direção a elas com novos projetos. Observemos essa explosão do real em } \\
\text { múltiplas possibilidades. [...] Cada vez mais se desfazem os limites entre o natural e o artificial. A capacidade } \\
\text { humana de transformar abre possibilidades. A poesia de Carlos Drummond de Andrade (1902-1987), por } \\
\text { exemplo, cria imagens diferentes de nosso cotidiano, levando a uma perspectiva de mundo que não conhecíamos. } \\
\text { [...] Podemos compreender que o ser humano é capaz de reinventar sua própria realidade e de pluralizar as } \\
\text { possibilidades de ver e de viver a vida. Leia, a seguir, um poema do autor (MARINA, 2010, p. 48-49). } \\
\text { Mãos dadas } \\
\text { Não serei o poeta de um mundo caduco. Também não cantarei o mundo futuro. Estou preso à vida e olho meus } \\
\text { companheiros. Estão taciturnos, mas nutrem grandes esperanças. Entre eles, considero a enorme realidade. O } \\
\text { presente é tão grande, não nos afastemos. Não nos afastemos muito, vamos de mãos dadas. Não serei o cantor } \\
\text { de uma mulher, de uma história, não direi os suspiros ao anoitecer, a paisagem vista da janela, não distribuirei } \\
\text { entorpecentes ou cartas de suicida, não fugirei para as ilhas nem serei raptado por serafins. O tempo é a minha } \\
\text { matéria, o tempo presente, os homens presentes, a vida presente. (MARINA, 20 10, p. 49); da obra (ANDRADE, } \\
\text { Carlos Drummond de. Sentimento do mundo. Rio de Janeiro: Mediafashion, 2008. v. } 4 \text {. (Col. Folha Grandes } \\
\text { Escritores Brasileiros). }\end{array}$ \\
\hline $\begin{array}{l}\text { b) Saiba mais } \\
\text { A realidade percebida pelos animais } \\
\text { É difícil imaginar como pode ser o mundo de um animal, considerando que não só sua inteligência, mas também } \\
\text { seus sistemas sensoriais são diferentes do nosso. Todavia, os animais captam estímulos que nós não captamos. O } \\
\text { ornitorrinco, por exemplo, percebe com seu bico, parecido com o dos patos, as descargas elétricas produzidas pelos } \\
\text { camarões, a um metro de distância. As abelhas percebem as alterações elétricas causadas por uma tempestade } \\
\text { distante e voltam para a colméia; as serpentes detectam o calor de suas vítimas; os morcegos percebem o eco dos } \\
\text { sons que lançam. O biólogo alemão Jakob Von Uexküll (1864-1944) assinalou que cada espécie animal vive em } \\
\text { um mundo próprio, ao que chamou Umwelt (MARINA, 2010, p. 50). }\end{array}$ \\
\hline $\begin{array}{l}\text { c) } \bigcirc \text { que é a verdade? } \\
\text { (a verdade como adequação): a verdade é a adequação entre o pensamento e a realidade. A idéia de verdade } \\
\text { como adequação é muito antiga. Os filósofos gregos já a defendiam (doc 6.). [...] o que se entende por } \\
\text { correspondência ou adequação. Os seres humanos conhecem a realidade de acordo com os órgão sensoriais. } \\
\text { "mundo humano" é diferente do "mundo do morcego", ainda que humanos e morcegos vivam na mesma realidade } \\
\text { e estejam submetidos às suas leis. Kant se deu conta desta dificuldade e afirmou que pensamos as coisas de acordo } \\
\text { com nossas estruturas mentais. E que não podemos saber o que é a realidade independentemente de nosso modo de } \\
\text { conhecer. [...] cada um de nós interpreta sua vida de modo particular, porque criou um sistema de preferências, de } \\
\text { crenças, e amores e ódios. [...] para saber se seu mundo está de acordo com a realidade, teria de sair e conhecer } \\
\text { a realidade, bem como comparar ambas as coisas: a representação e o mundo representado (MARINA, 2010, p. } \\
100 ; \text { aspas duplas do autor). }\end{array}$ \\
\hline
\end{tabular}


Onsino de filosofia nas perspectivas inter e transdisciplinar: uma análise da problemática ontológica

\section{Quadro 2}

Temáticas, problemas e definições (cont.)

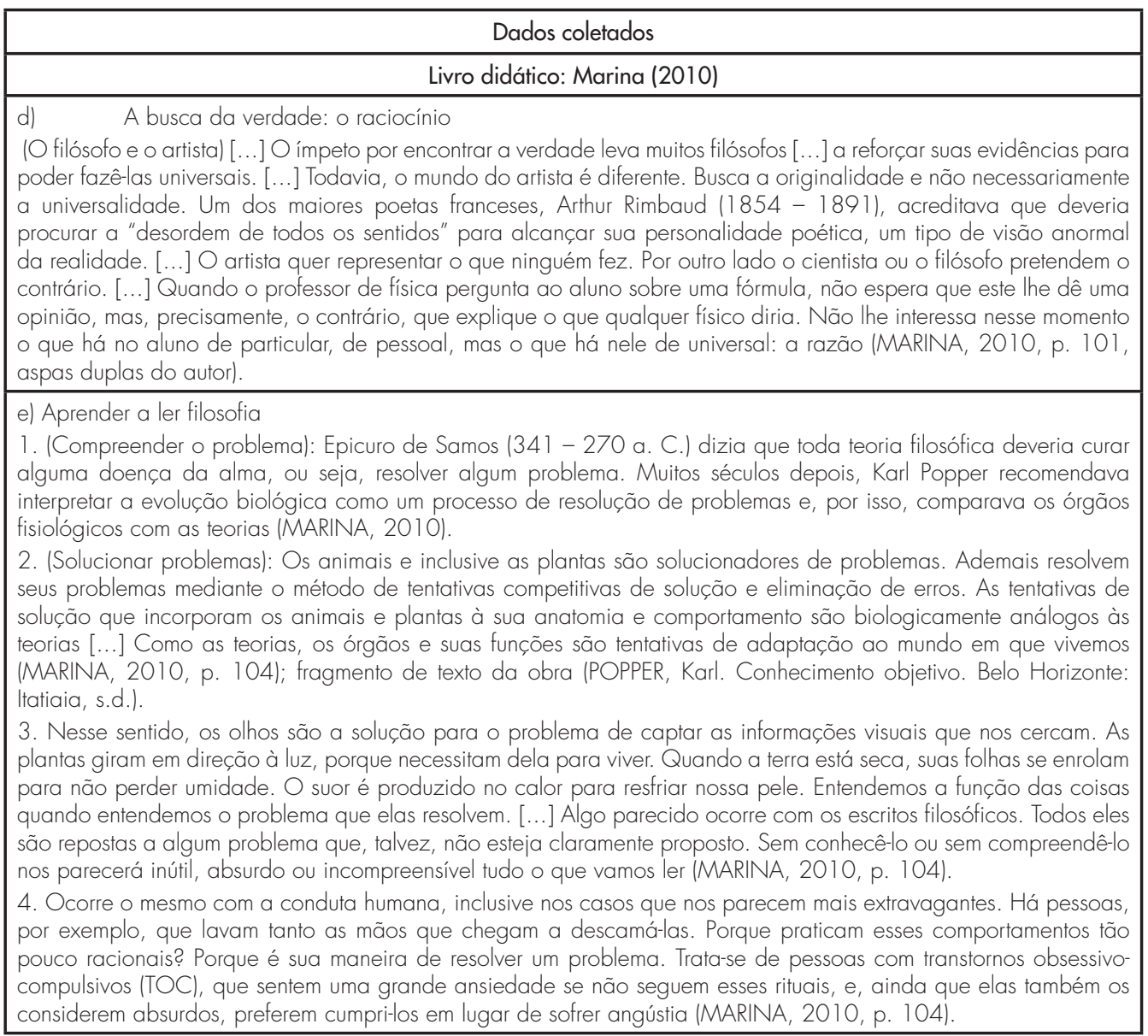

Fonte: Pesquisa bibliográfica (2013).

\section{Real, Irreal, Realidade}

A problemática ontológica foi introduzida pelo professor Fábio com a inserção de um texto que distinguia Real e Realidade. Assim, para o autor do texto, João H. Lacerda Ferreira, aquilo que se designa como Real engloba os seguintes conceitos: 
- Concreto: parte do Real, aquilo que existe objetivamente, ou seja, fora da mente humana, independente da existência e da percepção do ser humano. Cabe ressaltar, aqui, que essa definição de Concreto, como parte do Real, até certo ponto, assemelha-se à concepção de Realidade, proposta por Nicolescu (1999, p. 31 ), que se expressa do seguinte modo: "A Realidade não é apenas uma construção social, [...] Ela também tem uma dimensão transubjetiva, na medida em que um simples fato experimental pode arruinar a mais bela teoria científica."

- Modelo mental: consiste no modelo tridimensional sinestésico (sensações captadas e imagens mentais formadas sobre os objetos concretos) acrescido das ideias de valores culturais;

- Realidade humana: trata-se do conjunto dos modelos mentais acrescentando-se os modelos imaginários (instituições, por exemplo, a democracia) bem como as ilusões (que são reais enquanto ilusões).

Segundo Ferreira (2008), a categoria Real é muito mais ampla que a categoria Realidade; e não são sinônimos. Segundo o mencionado autor, ainda existe o conceito de Realidade Média, ou seja, aquela Realidade humana compartilhada por indivíduos do mesmo grupo cultural. Desse modo, Ferreira (2008) destaca que o homem se relaciona com uma Realidade Criada em sua mente (QUADRO 1, a).

Em conformidade com Ferreira (2008), o docente explicou para os estudantes do segundo ano que o conceito de Real abrangia "[... tudo o que existe, sendo concreto ou não, existente dentro e fora da mente humana" (DIÁRIO DE CAMPO, 201 2). Assim, "[...] para determinadas pessoas, algumas experiências pessoais são reais, mesmo não sendo observados por outras pessoas próximas; e, acrescentou que, geralmente, esses sujeitos são qualificados como loucos" (DIÁRIO DE CAMPO, 2012). Ademais, o professor referiu-se aos sujeitos que possuem doenças psicossomáticas. Segundo ele, vários sintomas descritos por esses pacientes, com exceção daqueles visíveis, tais como, manchas na pele, não podem ser verificados, objetivamente, em nenhum exame, no sentido de estritamente biológico.

Em outro texto, desta vez, segundo Marina (2010), há a explicitação de dois conceitos como fundamentais, a saber: o Real e o Irreal. Para o mencionado autor, o Real consiste naquilo que existe, independente de alguém experimentá-lo; algo que impõe limites, como uma parede, por exemplo; 
ensino de filosofia nas perspectivas inter e transdisciplinar: uma análise da problemática ontológica

e, nesse aspecto, aproxima-se tanto do citado conceito de Realidade de Nicolescu (1 999) quanto do conceito de Concreto de Ferreira (2008). Nesse sentido, o Irreal consistiria em algo que não imporia esse limite, por exemplo, uma parede imaginária (QUADRO 1, d). Todavia, há dissimilitude entre o conceito Irreal de Marina (2010) e a categoria de ilusão, mencionado por Ferreira (2008), porque a ilusão para esse autor faz parte do âmbito do Real e não do |rreal.

Ao considerar as argumentações apresentadas no texto de Ferreira (2008) e Marina (2010) tal como os acréscimos explanados na mediação docente, pode-se perceber que essa reflexão filosófica, ou seja, essa problematização ontológica, não faz referência a textos tradicionais da história da filosofia, e dispõe, indubitavelmente, de grandes potenciais para articular distintos conteúdos disciplinares. Esse potencial evidencia-se pelas inúmeras alusões a questões investigadas por outros campos do conhecimento, tais como, captações de sensações pelo organismo, formação de imagens e ilusões pela mente, valores dos grupos culturais, invenções de instituições sociopolíticas, doenças psicossomáticas, limitações dos exames biológicos e a relação mente e cérebro.

12 Desse modo, pode-se perceber uma intencionalidade docente em mediar o ensino sobre um problema filosófico numa perspectiva metadisciplinar visto que escolheu textos que apontavam para outros conteúdos disciplinares. Além disso, pela seleção desses materiais, Ferreira (2008) e Marina (2010), para realizar sua mediação didática, e, ainda pelas questões adicionadas à sua explanação, o docente iniciou a construção de uma interação modesta, já que feita solitariamente, entre filosofia e distintas Áreas do Conhecimento, por exemplo, Psicologias, Psicanálises, Psiquiatria, Neurologia, Antropologia, Sociologia e Biologia, entre outras.

Porém, outra vez, a gestão escolar, a coordenação pedagógica e o docente não planejaram coletivamente esse ensino com outros docentes e, especialistas das referidas áreas, a fim de elaborar conexões mais significativas (inter ou transdisciplinares). Na ausência desse trabalho coletivo e, mesmo comunitário, quer dizer, com a colaboração de especialistas da própria comunidade escolar, que pesquisam em Universidades próximas ou são profissionais liberais cujos filhos estudam no Colégio, perdeu-se a oportunidade de consolidar nesse ensino de filosofia o disposto em Brasil (2013, p. 27), a saber: "Essa [...] diversificação dos tempos e espaços escolares pressupõe profissionais 
da educação dispostos a reinventar [...] essa escola, numa responsabilidade compartilhada com [...] as demais autoridades [...], na busca de parcerias possíveis e necessárias [...]" bem como a elaboração de um saber interdisciplinar escolar, como indica Brasil (2000, p. 21 ; grifo nosso) de outra forma: articulação de conteúdos de várias disciplinas a fim de [...] "compreender um determinado fenômeno".

Ademais, a apreensão transdisciplinar sobre o Real, a Realidade ou a Natureza não se limita àquele conceito de Realidade apresentado por Nicolescu (1999). Essa concepção de Natureza inclui outras características. Contudo, antes de apresentar essas características referentes aos três pilares que constituem a visão de Natureza transdisciplinar, a saber: os Diferentes Níveis de Realidade, a Complexidade e a Lógica do Terceiro Incluído, faz-se necessário contextualizar algumas características da ciência moderna e as rupturas epistemológicas que ocorreram no início do século XX. Essas rupturas foram as catalisadoras da concepção de um novo paradigma científico e de uma nova compreensão da Complexidade do Real.

Características da "ciência tradicional ou clássica" e as rupturas epistemológicas do século XX: uma breve contextualização

Por "ciência tradicional" ou "clássica" compreende-se o modelo científico, configurado entre os séculos XVII e XVIII, cujos fundamentos teóricos sofreram abalos sucessivos com o desenvolvimento da física, da segunda metade do século XIX e primeira metade do século XX. Como fundamentos do paradigma "clássico", que opera por separação entre o observador e a realidade observada, Nicolescu (1999, p. 19-20) apresenta os seguintes postulados: "1. A existência de leis universais de caráter matemático. 2. A descoberta dessas leis pela experiência científica. 3. A reprodutibilidade perfeita dos dados experimentais."

Assim, a matemática foi instituída como a linguagem universal da ciência moderna; como a física se adaptava, perfeitamente, aos três postulados citados anteriormente, ela se consolidou como um modelo de cientificidade. Logo, três conceitos fundamentais orientavam as pesquisas da física clássica: a continuidade, a causalidade local e o determinismo. Sobre esses conceitos, Nicolescu (1999) esclarece que: 
ensino de filosofia nas perspectivas inter e transdisciplinar: uma análise da problemática ontológica

[...] continuidade, [ ...] não se pode passar de um ponto a outro do espaço e do tempo sem passar por todos os pontos intermediários. [...] a causalidade local. [...] dois pontos separados [...] no espaço e no tempo, estão, todavia ligados por um encadeamento contínuo de causas e efeitos: [...] determinismo [...] se soubermos as posições e as velocidades dos objetos físicos num dado instante, podemos prever suas posições e velocidades em qualquer outro momento do tempo (NICOLESCU, 1999, p. 20-21).

Entretanto, no início do século XX, Max Planck descobriu que a energia tem uma estrutura descontínua, ou seja, "[...] entre dois pontos não há nada, nem objetos, nem átomos, nem moléculas, nem partículas, apenas nada" (NICOLESCU, 1999, p. 25-26). Consequentemente, a ideia de descontinuidade entra na ciência moderna pela microfísica, estabelecendo um paradoxo com a ideia de continuidade do nível macrofísico. Ademais, outra descoberta dessa época, que se tornou inquestionável nos anos 1970, foi a compreensão de que outra causalidade age no mundo microfísico: a causalidade global. Essa causalidade foi evidenciada porque as [...] "[.... entidades quânticas continuam a interagir qualquer que seja o seu afastamento" (NICOLESCU, 1999, p. 27); quer dizer, essas entidades são muito diferentes dos objetos da física clássica: os corpúsculos e as ondas. "[...] As célebres relações de Heisenberg mostram, sem nenhuma ambiguidade, que é impossível localizar um quantum num ponto preciso do espaço e num ponto preciso do tempo" (NICOLESCU, 1999, p. 28-29). Pelo exposto, evidencia-se que a causalidade local não opera em toda a Realidade, mas apenas no âmbito macrofísico.

Nesse contexto de rupturas científicas paradigmáticas, foram desconstruídas não somente as ideias de que a continuidade e a causalidade local operam em toda a Natureza, mas também a ideia de separabilidade; principalmente a separação clássica entre sujeito e objeto. Assim, emerge o conceito de não-separabilidade. Ademais, há um indeterminismo reinante na escala quântica, que não é devido à incapacidade dos pesquisadores em organizar os dados e informações e, assim, perceber uma ordem quântica. Trata-se, porém, de um indeterminismo constitutivo, em outras palavras, ontológico, intrínseco ao nível de Realidade microfísico. Esse indeterminismo também não se assemelha às concepções de acaso ou ainda imprecisão, mas se trata de uma nova concepção: o aleatório quântico. Assim, " [...] é impossível [...] dizer qual é o átomo que se desintegra num momento preciso. [...] $\bigcirc$ aleatório quântico 
é um aleatório construtivo, que tem um sentido: o da construção de nosso próprio mundo macrofísico" (NICOLESCU, 1999, p. 19). Dessa maneira, o físico salienta que "Uma matéria mais fina penetra uma matéria mais grosseira. As duas co-existem, cooperam numa unidade que vai da partícula quântica ao cosmo" (NICOLESCU, 1999, p. 19).

Considerando todas essas rupturas, inerentes ao próprio desenvolvimento do modelo clássico de ciência, iniciaram-se questionamentos não apenas científicos, mas também filosóficos, ou melhor, ontológicos, da existência de um único nível de Realidade. Por conseguinte, teve início um processo de formalização de conjecturas acerca da existência de uma Realidade ou Natureza organizada em pelo menos dois níveis, com leis e lógicas de organização diferentes.

Os diferentes níveis de Realidade

A problemática relativa à gênese e à organização da Realidade esteve presente, de modo sistemático, nas investigações dos pesquisadores, desde os primeiros filósofos gregos. Esses pensadores, entre os séculos VII a $\vee$ a.C., denominados de filósofos pré-socráticos, queriam compreender a natureza do mundo; a physis. Eles indagavam a respeito do princípio ou o elemento que originou todas as coisas e, que reduzisse a multiplicidade percebida a uma unidade exigida pela razão (REALE, 1993). Nesse sentido, em outros períodos da história da filosofia, aconteceram, também, investigações sejam ontológicas, sejam metafísicas, como tentativas de explicar a origem da Realidade.

Entretanto, as rupturas epistemológicas emergentes na microfísica conduzem ao questionamento da unidade da Realidade e da validade universal do princípio de identidade da lógica aristotélica. Assim, essa Natureza, Real ou Realidade era sempre pensada como constituída por um único nível e organizada conforme uma única lógica e os mesmos princípios fundamentais.

Previamente, segundo Nicolescu (1999, p. 30-31), a Realidade é "[...] aquilo que resiste às nossas experiências, representações, descrições, imagens ou formalizações matemáticas. [...] A Natureza é uma imensa e inesgotável fonte de desconhecido que justifica a própria existência da ciência" (NICOLESCU, 2001, p. 121). Além disso, os níveis de Realidade são 
ensino de filosofia nas perspectivas inter e transdisciplinar: uma análise da problemática ontológica

conceituados como "[...] um conjunto de sistemas que não variam sob a ação de um número de leis gerais" (NICOLESCU, 2001, p. 121). Em face do exposto, evidenciou-se que as entidades quânticas não se submetem às leis e lógica do nível de Realidade macrofísico, quer dizer, essas entidades são inatingíveis por essas leis e não se comportam em conformidade com essa lógica e vice-versa.

Todavia, essa descontinuidade não impede a coexistência de dois "mundos"; por exemplo, "[...] nossos corpos têm, ao mesmo tempo, uma estrutura macrofísica e uma estrutura quântica" (NICOLESCU, 2001, p. 122). Nesse sentido, há a distinção de dois níveis de Realidade quando, "[...] passando de um ao outro, houver ruptura das leis e dos conceitos fundamentais (como, por exemplo, a causalidade)" (NICOLESCU, 2001, p. 31 ). Portanto, pode-se perceber que os níveis de Realidade têm estados distintos de materialidade e de complexidade. Ademais, o conceito de energia, no mundo quântico, unifica os conceitos de substância, informação e espaço-tempo. Desse modo, "[...] a informação é uma energia codificada, enquanto a substância é uma energia concretizada" (NICOLESCU, 1999, p. 72; grifos do autor). Além do mais, o espaço-tempo "[...] é uma conseqüência da presença 16 da matéria" (NICOLESCU, 1999, p. 72).

Os diferentes níveis de organização, de percepção e de representação

Conforme Nicolescu (2001, p. 122, grifo nosso), "[...] os níveis de organização não pressupõem uma ruptura dos conceitos fundamentais: vários níveis de organização pertencem a um único e mesmo nível de Realidade" . Dessa maneira, os elementos que constituem os distintos níveis de organização, tais como, o nível físico e o biológico, organizam-se de maneiras diferentes, todavia essas estruturações estão submetidas às leis fundamentais daquele nível de Realidade do qual são constituintes.

Outrossim, existem também os níveis de percepção que possibilitam uma visão cada vez mais profunda e geral da Realidade ou Natureza transdisciplinar, porém, sem jamais esgotá-la. E, de acordo com Nicolescu (200 1, p. 134), "[...] os diferentes níveis de Realidade são acessíveis ao conhecimento humano graças à existência de diferentes níveis de percepção, que se encontra em correspondência biunívoca com os níveis de Realidade". 
É possível ainda destacar os níveis de representação. Esses níveis são formados pela convergência entre os diferentes níveis de Realidade e os distintos níveis de percepção do pesquisador. Assim, um determinado nível de representação pode apresentar-se como barreira que impede o cientista, o artista, o filósofo de captar as imagens produzidas por outro nível de representação.

\section{Multidimensionalidade e a Multirreferencialidade}

A Realidade, na perspectiva transdisciplinar, caracteriza-se por sua multidimensionalidade em contraposição à tradicional visão unidimensional do pensamento "clássico". Mas, a Natureza transdisciplinar é, também, multirreferencial, pois "nenhum nível de Realidade constitui um lugar privilegiado de onde possamos compreender todos os outros níveis de Realidade" (NICOLESCU, p. 134).

Em face do exposto, constatou-se com as observações que, em nenhuma das aulas de filosofia, o professor Fábio explanou sobre esses assuntos tratados anteriormente nos itens 1.1.1; 1.1.2; 1.1.3; 1.1.4. No entanto, o Colégio tem, em seu projeto político-pedagógico, como meta, para ser alcançada em seu programa educacional "[...] a abordagem das temáticas escolares numa perspectiva transdisciplinar da realidade" (DIÁRIO DE CAMPO, 2012 2). E, os Planos Anuais do Curso de filosofia, para os três anos do ensino médio, elaborados pelo docente, destacava como subtítulo que se tratava de uma "proposta interdisciplinar de ensino" (DIÁRIO DE CAMPO, 2012)

Ademais, como de costume, não houve um planejamento conjunto entre os docentes, no caso em questão, de filosofia e física a fim de explicitar aos estudantes essas indagações. Além disso, esses assuntos elencados são indispensáveis para problematizar questões ontológicas uma vez que esse assunto se refere ao que há de mais intrínseco, essencial à organização da Natureza. Destarte, não é mais possível isolar esses assuntos como exclusividades da física ou desconsiderá-los na filosofia. É necessário interligar ensino de física e ensino de filosofia. 
Onsino de filosofia nas perspectivas inter e transdisciplinar: uma análise da problemática ontológica

\section{Humanização, construção e significação do Real ou Realidade}

Marina (2010) discorre sobre a problemática ontológica também em outras perspectivas. A primeira delas destaca a necessidade de o ser humano conhecer e prever os desafios colocados pela Realidade. Dessa maneira, tanto a filosofia como as ciências teriam por objetivo conhecer o Real ou Natureza, prever sua manifestação e humanizá-la. Contudo, a filosofia distancia-se das ciências por pretender não somente conhecer a Realidade, mas também humanizá-la justificadamente. Essa humanização consistiria em significar os objetos tornando o mundo compreensível, humano e a Realidade habitável IQUADRO $1, b)$.

Assim, para salientar a necessidade humana em viver criativamente construindo sua Realidade, Marina (2010) introduz um verso do poeta alemão Friedrich Hölderlin e, em seguida o relaciona com os três grandes projetos da inteligência humana que, segundo o autor do livro didático, consistiriam em: conhecer, transfigurar esteticamente e humanizar a Realidade IMARINA, 2010). Desse modo, o autor instaura uma comunicação entre filosofia e literatura, mais especificamente a poesia, '[...] como uma simples comunicação

18 de idéias [...] essa "interdisciplinaridade singela" [...]", destacada em Brasil (2000 b, p. 75-76; grifo do autor); que foi aproveitada modicamente na mediação docente.

Na segunda perspectiva, Marina (2010) define o termo ontologia a partir da expressão grega tou óntos logos, destacando o objeto de estudo da ontologia: o ser. Mas, como a teoria da complexidade concebe o ser? Antes de qualquer coisa, Morin (2008a, p. 254-255; grifo nosso) explica que a existência é ao mesmo tempo imersão em um ambiente e desapego em relação a esse ambiente posto que o "[...] existente é o ser que está sob a dependência continua daquilo que o cerca [...] Mas, é preciso, ao mesmo tempo, certa autonomia [...] individualidade para existir" (MORIN, 2008a, p. 255, grifo nosso). Nesse sentido, a existência é abertura e fragilidade. 0 ser aberto ou existente está próximo da ruína desde o seu nascimento "[...] pelo dinamismo ininterrupto da organização permanente [...] Sua existência só pode oscilar entre o equilíbrio e o desequilíbrio, [...] Tudo o que está aberto vive sob ameaça de morte e da ameaça da morte", (MORIN, 2008a, p. 255, grifo nosso), visto que essa existência "é um sendo transitivo, incerto" (MORIN, 
2008a, p. 255, grifo do autor), e, porque "toda existência se alimenta do que a corrói" (MORIN, 2008a, p. 255, grifos do autor).

Nessa ótica, "[...] a ideia de ser não é uma noção substancial. É uma ideia organizacional [uma vez que] não há ser onde há dispersão, há emergência de ser ali onde há organização" (MORIN, 2008a, p. 260-26 1, grifo nosso). Assim, "[...] a abertura produz existência: o circuito generativo produz o ser" (MORIN, 2008a, p. 26 1). Como a produção do ser e da existência dá-se num circuito, não se pode separá-los. Para o autor, "Ser, com efeito, é permanecer constante em suas formas, sua organização, sua geracidade, ou seja, sua identidade". Por conseguinte, "[...] a existência é a qualidade de um ser que se produz sem parar, e que se desfaz assim que há falha nessa produção de si ou reorganização" (MORIN, 2008a, p. 261 ; grifo nosso). Ademais, ser e si estão estreitamente ligados. A produção do ser contém essa qualidade ou realidade denominada si; e, visto que o ser tem o si, pode produzir-se.

De acordo com Morin (2008a, p. 262, grifo do autor), "[...] o si é o que nasce de si mesmo, o que se volta para si, como no pronome reflexivo si, o que volta a si, o que recomeça de si, (na regeneração, na organização)". Desse modo, o si trata-se de uma ideia fundamental já que constitui o fechamento original e essencial dos sistemas abertos, [...]. Em suma, no mesmo circuito, são "[...] gerados pela práxis o ser, pela abertura a existência, pela organização, autonomia, pela recursão, o si $(M O R I N, 2008$ a, p. 264; grifo nosso).

Além disso, Marina (2010) refere-se seja a seres reais ou irreais e, como exemplo de ser irreal, mas que existe de alguma forma, o autor cita uma famosa personagem da literatura (QUADRO 1, c). Assim, o autor do livro didático recorre, novamente, à literatura para explicitar um problema filosófico. Ademais, ele distingue o propósito da ontologia, no tocante ao estudo do ser, dos objetivos das demais ciências que investigam os seres (MARINA, 2010).

Na perspectiva da complexidade, para Morin (2000), a Natureza ou Realidade é cogitada como um Todo cujas partes, elementos ou fenômenos são interdependentes. Essas partes interagem e retrointeragem entre si uma vez que esses diferentes elementos constitutivos são inseparáveis. Assim, a pluralidade de dimensões ou recortes do Real, definidos pelas ciências contemporâneas, tais como, o físico, o biológico, o sociológico, o psicológico, o mitológico, o econômico e os saberes escolares relacionados a cada uma 
Onsino de filosofia nas perspectivas inter e transdisciplinar: uma análise da problemática ontológica

dessas especializações, devem ser considerados em conjunto nos processos da pesquisa científica e filosófica bem como na educação escolar. Na atualidade, existem variados problemas complexos como, por exemplo, o ecológico cuja busca de soluções demandam a interligação de muitos saberes disciplinares.

No que diz respeito às relações entre ciências e filosofia, Japiassu (1976, p. 203) não só destaca a tendência disciplinar de se fechar sobre a perspectiva de seu objeto, mas também salienta que a função da filosofia, em relação ao movimento de ligação dos saberes, "[...] é manter aberto um espaço mental que resista a toda tentativa de confinamento ou reducionismo epistemológico".

Por esse ângulo, Brasil (2002, p. 44; grifo do autor) frisa que o saber filosófico caracteriza-se por examinar

[...] os problemas sob a perspectiva de conjunto - enquanto as ciências particulares abordam "recortes" da realidade - o que permite à Filosofia elaborar uma visão globalizante, interdisciplinar e mesmo transdisciplinar (metadisciplinar); não trata de um objeto específico, como nas ciências, porque nada escapa ao seu interesse, ocupando-se de tudo.

Eis aqui uma concepção de filosofia, numa orientação oficial, que favorece, consideravelmente, a ideia de relacionar várias disciplinas com base em uma temática filosófica. Porém, o estabelecimento de relações mais significativas inter-, e/ou transdisiplinares dependeria de um trabalho coletivo docente; não realizado em nenhuma das aulas observadas. Em oposição a esse modo isolado de mediar o ensino pelo professor, Brasil (2006, p. 39) orienta o seguinte: "[...] ciente do que the é próprio, o profissional de filosofia poderá desenvolver projetos em conjunto, inclusive com temas transversais e interdisciplinares, enriquecendo o ensino [...]".

Na terceira perspectiva, o autor do livro didático, destaca que a ontologia propõe problemas para as ciências, por exemplo, a física e as ciências sociais. Ambas estão repletas de questões que não são científicas, necessitando de fundamentação ontológica. Dito de outro modo, as afirmações e conceitos científicos necessitam de um princípio ontológico que os embase (QUADRO 1, c. 1). Por isso, a teoria da complexidade, destaca a necessidade permanente de reflexividade entre ciências e filosofias uma vez que 'não há fronteira "natural" entre elas' (MORIN, 2005a, p. 28; grifo do autor). [...] 
Com efeito, "[...] ciência e filosofia fazem parte da mesma tradição crítica, cuja perpetuação é indispensável à vida de ambas" (MORIN, 2005a, p. 28). Logo, elas podem ser consideradas como "[...] duas faces diferentes e complementares do mesmo: o pensamento (MORIN, 2005a, p. 30). Nessa direção, pode-se destacar que, a filosofia "[...] abre o espaço por excelência para tematizar e explicitar os conceitos que permeiam todas as outras disciplinas, e o faz de forma radical, ou seja, buscando suas raízes ou fundamentos e pressupostos; [...] (BRASIL, 2002, p. 44; grifo nosso).

Na quarta perspectiva, o autor do livro didático apresenta o Real como um mundo de possibilidades pelas quais o ser humano pode realizar seus projetos. Além disso, Marina (2010) evidencia que a capacidade humana para transformar a Realidade tem desfeito os limites entre o natural e o artificial. Nesse sentido, para ilustrar a capacidade humana de reinventar sua própria Realidade e de multiplicar as possibilidades de interpretar e viver a existência, Marina (2010), apresenta uma poesia de Carlos Drummond de Andrade (QUADRO 2, a). Essa recorrente insistência, do autor do livro didático, em buscar relacionar literatura, filosofia e ciências, em seus textos, com o intuito de perscrutar uma temática filosófica está em conformidade com as orientações do Congresso Internacional de Locarno, quando explicita a necessidade de haver educadores animados por uma atitude transdisciplinar que considere o diálogo arte/ciência como um dos maiores "[...] eixos da nova educação, visando à reunificação das duas culturas artificialmente antagônicas: a cultura científica e a cultura artística, [...] mediante uma nova cultura multidimensional, [ ...]" (CONGRESSO DE LOCARNO, 1997, p. 7).

Esse diálogo propicia, sem dúvida, aos docentes a possibilidade de organizar um ensino de filosofia com intensos diálogos inter- ou, possivelmente, transdisciplinares. No entanto, esses textos, apresentados por Marina (2010), ou foram aproveitados modicamente pelo docente ou não foram utilizados, tal como, o próprio texto do (Quadro 2, a). Apesar disso, em consonância com o autor do livro didático, no âmbito do discurso normativo sobre as competências e habilidades que o professor deve auxiliar os estudantes a desenvolver, Brasil (2006, p. 33; grifo nosso) enfatiza o seguinte: "[...] ler, de modo filosófico, textos de diferentes estruturas e registros [...] articular conhecimentos filosóficos e diferentes conteúdos e modos discursivos nas Ciências Naturais e Humanas, [...]" bem como "nas Artes e em outras produções culturais" (BRASIL, 2006, p. 33). Além disso, no tocante a um dos pilares da transdisciplinaridade, ou 
ensino de filosofia nas perspectivas inter e transdisciplinar: uma análise da problemática ontológica

seja, a Complexidade, nenhum de seus aspectos foi abordado nas aulas de filosofia. Todavia, considerando a intencionalidade dada por Fábio ao ensino observado, serão evidenciados, em seguida, alguns de seus pormenores.

\section{A complexidade}

Segundo Morin (2000, p. 38), o termo "[...] complexus significa o que foi tecido junto", portanto, por pensamento complexo pode-se compreender uma reflexão multidimensional e multirreferencial sobre a Realidade cujos elementos ou fenômenos são interpretados de maneira complementar, e, às vezes, concorrente e antagônica, ao mesmo tempo. Essa reflexão deve considerar a interação entre esses fenômenos e seus contextos, problematizando das partes ao todo e do todo para as partes, concebendo a união entre unidade e multiplicidade

Em face do exposto, Morin (2005) destaca que o grande paradigma ${ }^{5}$ ocidental, formulado, principalmente, pelas contribuições de René Descartes, no século XVII, coloca como princípio de verdade a busca pelas ideias claras e distintas. Esse paradigma que, também, separou, de um lado, sujeito pensante (res cogitans) e, de outro, objeto (res extensa), difundiu-se por todos os âmbitos das pesquisas científicas, e, é denominado, pelo referido autor, de paradigma da simplificação. Com efeito, Descartes explicita o seguinte: "[...] jamais acolher alguma coisa como verdadeira [...] em meus juízos que não se apresentasse tão clara e distintamente ao meu espírito, que eu não tivesse nenhuma ocasião de pô-lo em dúvida" (DESCARTES, 1979, p. 45-46). A esse paradigma, Morin contrapõe um paradigma de complexidade, e se expressa do seguinte modo: "[...] chamo de paradigma da simplificação [aquele que produz] uma concepção simplificadora do universo [...]. Chamo paradigma da complexidade [aquele que determina] as condições de uma visão complexa do universo [...]" (MORIN, 2005, p. 330).

Além disso, Morin (2008, p. 112 ) esclarece que o paradigma da simplificação "[...] se baseia sobre o domínio de dois tipos lógicos de operação: disjunção e redução" enquanto o paradigma da complexidade fundamenta-se nos operadores lógicos da "[...] distinção, de conjunção e de implicação" (MORIN, 2008, p. 1 12). Por exemplo: o homem é um ser cultural e biológico, concomitantemente. "Ora estas duas realidades [...] o paradigma da 
simplificação obriga-nos quer a separá-los quer a reduzir a mais complexa a menos complexa". No entanto, o paradigma da complexidade distingue essas duas dimensões uma vez que o biológico não é o cultural e vice-versa, associa essas dimensões, simultaneamente, complementares e antagônicas, todavia, constitutivas do ser humano e esclarece que ambas estão implicadas, isto é, não há dimensão antropossocial sem dimensão biológica visto que da dimensão biológica emergiu a antropossocial.

Além do mais, em relação à mediação didático-pedagógica, num contexto de debate em sala de aula, criou-se uma discussão em torno dos "[...] diferentes instintos e capacidades animais e sobre a possibilidade deles possuírem uma inteligência no sentido de capacidade inventiva" (DIÁRIO DE CAMPO, 2012). Em meio à discussão, o estudante Bruno apresentou uma definição de inteligência que incluiu tanto os animais como os seres humanos. Para ele "[...] a inteligência relaciona-se à capacidade de perceber o espaço e utilizá-lo para seu bem estar" (DIÁRIO DE CAMPO, 2012).

No que concerne ao conceito que Bruno apresentou, consideramoto em consonância com a teoria da complexidade, uma vez que ele enuncia uma concepção de inteligência que esclarece, simultaneamente, um comportamento humano e animal; quer dizer, trata-se de um conceito dialógico, visto que distingue (porque a dimensão humana não é a animall), mas também une dimensões consideradas como opostas; humana e animal. Há que se ressaltar também a implicação, ou seja, ser um humano implica ser um animal, porém, mais que isso, já que é racional e possuidor de outras características. Em outras palavras, o homem e a mulher são humanos e animais, ao mesmo tempo. Consequentemente, ainda se trata de um conceito sintético, quiçá, interdisciplinar, visto que ele faz uma ligação entre seres humanos e animais e, para explicitar aspectos desse conceito pode-se utilizar conteúdos disciplinares da biologia, filosofia, geografia, sociologia, entre outras disciplinas.

Nessa ótica, a Carta da Transdisciplinaridade, salienta o seguinte: "A visão transdisciplinar está resolutamente aberta na medida em que ela ultrapassa o domínio das ciências exatas por seu diálogo e sua reconciliação não somente com as ciências humanas, mas também com a arte, a literatura, a poesia e a experiência espiritual" (CONGRESSO DE ARRÁBIDA, 1994, p. 2). 
Onsino de filosofia nas perspectivas inter e transdisciplinar: uma análise da problemática ontológica

\section{A Impossibilidade de conhecer o Real ou a Realidade em si}

Sobre essa problematização do Real ou Realidade em si, Marina (2010) introduz e explicita um conteúdo relativo à distinção entre os modos de perceber a Realidade pelos homens e os animais. Nessa direção, o autor destaca que cada animal percebe o mundo de forma distinta uma vez que seus sistemas sensoriais são muito diferentes do nosso, captando estímulos que não percebemos. Assim, mesmo vivendo na mesma Realidade regida pelas mesmas leis nossas percepções sobre o mundo sempre serão distintas (QUADRO 2 , b). O mencionado autor notabiliza, ainda, certas características especificas de alguns animais, por exemplo: o ornitorrinco, as abelhas, as serpentes e os morcegos.

Além disso, Marina (2010) menciona o conceito Umwelt, do biólogo alemão Jakob Von Uexküll (1864-1944), que tem por finalidade explicar que cada gênero animal vive numa espécie de mundo próprio. Mais uma vez, Marina (2010) utiliza-se de alusões a informações de outro campo disciplinar, no caso, a biologia, para problematizar um tema filosófico, ou melhor, ontológico. Porém, dessa vez, o docente, a partir da explanação do texto didático,

24 utilizou as informações da biologia, intensificando a problematização.

Ademais, em outro tópico de Marina (2010), o autor cita dois filósofos: Epicuro de Samos, para quem a filosofia deveria resolver algum problema e Karl Popper, que interpretava a evolução biológica como processo de solução de problemas. Popper comparava as funções dos órgãos fisiológicos às teorias científicas (QUADRO 2, e. 1, 2, 3). Além disso, acrescenta que a condição humana segue o mesmo modelo. A título de exemplo, o autor refere-se às pessoas que têm TOC (Transtorno Obsessivo Compulsivo) (QUADRO 2, e. 4). No que se refere à mediação docente, o professor Fábio deteve-se em comentar a problemática enfrentada pelas pessoas com TOC e não explicitou as outras problematizações elencadas por Popper. É possível perceber, porém, que se houvesse um planejamento conjunto das aulas, a temática introduzida por Marina (2010) teria grandes possibilidades de estabelecer ligações inter ou, talvez, até transdisciplinares entre docentes e discentes. Ainda, Fábio problematizou, a respeito da crítica filosófica de Kant, a possibilidade de conhecer a Realidade em si (QUADRO 2, c).

Para mais, Morin (2005a, p. 234), referindo-se à revolução copernicana de Kant, destaca que o kantismo ignorou a segunda parte de um 
paradoxo fundamental: "[...] o nosso mundo é produzido pelo nosso espírito; mas ignora que este foi co-produzido pelo mundo"; visto que nossas estruturas mentais vêm do mundo natural, aliás, de uma evolução natural/cultural. Nesse sentido, o autor propõe uma concepção de Realidade que, segundo ele, supera o criticismo kantiano, num "realismo relacional, relativo e múltiplo" (MORIN, 2005a, p. 245; grifos do autor). Relacional visto que a "relação sujeito/objeto e espírito/mundo", Morin (2005a, p. 245); é indissociável. Relativo haja vista "[...] a relatividade dos meios de conhecimento e da relatividade da realidade cognoscível", (MORIN, 2005a, p. 245). E, enfim, Múltiplo por causa da "multiplicidade dos níveis de realidade [...] (MORIN, 2005a, p. 245).

Marina (2010) insere, ainda, em sua obra didática, as diferentes óticas pelas quais os filósofos, cientistas e artistas veem o mundo. $\bigcirc$ autor destaca que, enquanto o filósofo ou o cientista se interessam em reforçar suas evidências para torná-las universais, o artista, de modo geral, interage com a Realidade, por sua personalidade poética e originalidade buscando exprimir o que ainda ninguém fez (QUADRO 2, d). Sobre essa mesma questão, a título de exemplo, oriundo do ensino de física, Marina (2010) salienta que, ao fazer uma pergunta a um estudante, o professor de física espera como resposta uma fórmula, uma definição universal e não uma opinião pessoal do discente. Pelo exposto, mais uma vez o texto do autor do livro didático propicia a abertura do diálogo entre as disciplinas, em específico, filosofia, física e artes. No tocante à mediação didática, Fábio destacou as distintas visões de mundo entre o artista, o cientista e o filósofo. Considera-se que a problematização teria sido bem mais profunda se um docente de física e um artista tivessem participado do planejamento e mediação da aula; e, talvez, esse ensino de filosofia se aproximasse, pelo menos, de uma vivência interdisciplinar.

\section{Considerações finais}

Considerando o que foi observado no conjunto das aulas sobressaem, em seguida, algumas ponderações com base na análise e na interpretação dos dados apresentados.

Em primeiro lugar constatou-se que, para o Colégio aproximar-se mais da sua meta de educar transdisciplinarmente, é necessário que os profissionais 
Onsino de filosofia nas perspectivas inter e transdisciplinar: uma análise da problemática ontológica

da educação que ali trabalham (gestores, coordenadores pedagógicos, docentes), realmente, conheçam tanto a concepção transdisciplinar de Realidade quanto a concepção transdisciplinar de Educação; pois, esse conhecimento, não foi evidenciado em nossas investigações. Além disso, é preciso reorganizar a unidade educacional segundo a concepção educacional que dispuseram no Projeto Político-Pedagógico. Em seguida é fundamental salientar que os docentes do Colégio necessitam passar a vivenciar o trabalho coletivo, em ambientes de aprendizagens mútuos, onde aconteçam um planejamento e a apropriação coletiva de um conhecimento que, de fato, emerja dos contatos disciplinares ocorridos entre eles. Essa apropriação e planejamento conjunto das aulas por eixos temáticos ou temas estruturadores é condição essencial para construir com os discentes um processo ensino-aprendizagem inter-, ou transdisciplinar. Nesse sentido, também são necessárias avaliações contínuas desse processo de ligação dos saberes.

Ademais, também é indispensável que a gestão escolar flexibilize a carga horária docente e os remunere melhor, visando lecionar exclusivamente no Colégio, a fim de que as aulas aconteçam em ambientes de aprendizagem, dentro ou fora da escola, sempre com a participação de pelo menos dois 26 professores de distintas disciplinas; e, nessa mediação conjunta ser possível, de modo mais profundo, relacionar os conteúdos ensinados. É, ainda, necessário, propiciar e experimentar com os estudantes, vivências culturais, sociais e políticas mais significativas nesses ambientes. Também é imprescindível que as características da visão transdisciplinar de Realidade e Conhecimento, com as devidas adaptações para a educação escolar, se transformem em conteúdos de ensino.

No entanto, apesar desses obstáculos e contradições observados na organização do Colégio, faz-se mister ressaltar que, o material didático selecionado pelo professor Fábio, a nosso ver, é extremamente pertinente; considerando sua intencionalidade em mediar um ensino de filosofia inter-, e transdisciplinar. Além do mais, é preciso frisar que esse docente trabalha há mais de trinta anos lecionando as disciplinas de filosofia, história e sociologia. E, esse saber docente prático e eminente, associado ao material didático que ele selecionou, possibilitou um ensino de filosofia bem versátil; como podem evidenciar os dados apresentados.

No que se refere aos assuntos tratados nas aulas, evidenciou-se que embora as relações disciplinares estabelecidas pelo docente e estudantes, nas 
problematizações ontológicas, por vezes, se limitassem a alusões, menções ou referências a conteúdos de outras disciplinas, presentes nesses textos didáticos, as observações demonstram que esse material propiciou a explicitação de "pontes" ou vínculos disciplinares, dentro dos limites institucionais e pessoais (docente) já expostos. Nesse sentido, áreas de conhecimento, disciplinas científicas e algumas de suas hiperespecializações, tais como: psicologia, psicanálise, psiquiatria, neurologia, antropologia e ciências sociais foram articuladas nos textos de Marina (2010) e alguns excertos de textos foram utilizados na mediação docente. Outrossim, a conexão entre material didático e explanações docentes propiciou aos estudantes, pelo menos, a visão de que disciplinas, tais como, filosofia, biologia, geografia, literatura, artes, matemática e física devem ser vinculadas para melhor compreender a Natureza ou Realidade.

Dessa forma, os conteúdos articulados nas aulas envolveram áreas ou disciplinas não adjacentes o que faz descartar a possibilidade de denominar esse ensino de filosofia de pluridisciplinar. Ademais, em virtude dos obstáculos e contradições mencionados, evidentemente, esse ensino de filosofia também não configurou como inter ou transdisciplinar. Por isso, em face dos argumentos, apresentados conclui-se, como no primeiro artigo, que esse ensino de filosofia configurou como uma vivência (experiência) de multidisciplinaridade escolar "modesta"; conquanto mais versátil que as aulas sobre os conteúdos epistemológicos.

\section{Notas}

1 SILVA, Gilson Malta da. $\bigcirc$ ensino de filosofia nas perspectivas inter e transdisciplinar: a problemática do conhecimento. Griot: Revista de Filosofia, Amargosa, Bahia, v. 16, n. 2, p. 398-422, dezembro de 2017.

2 A contextualização busca desenvolver aprendizagens significativas que são produzidas evocando-se "áreas, âmbitos ou dimensões presentes na vida pessoal, social e cultural dos discentes" (BRASIL, 2000 a, p. 78).

3 Conforme as alterações na Lei de Diretrizes e Bases da Educação Nacional (LDB), art. 35- A, feitas pela Lei 13.415 de 16 fev. de 2017; ainda sem Diretrizes do Conselho Nacional de Educação (CNE). No entanto, as Diretrizes Curriculares Nacionais para o Ensino Médio, Brasil (2013a, p. 195, art. 8\%), já dispunham de modo semelhante: Linguagens; Matemática; Ciências da Natureza; Ciências Humanas.

4 Os nomes são fictícios 
Onsino de filosofia nas perspectivas inter e transdisciplinar: uma análise da problemática ontológica

5 Para Morin (2008, p. 15) são os princípios "supralógicos", que organizam os raciocínios e os conhecimentos, e conduzem o pesquisador a selecionar determinados dados em detrimentos de outros; "separa (distingue ou desune) e une (associa, identifica) e hierarquiza (o principal, o secundário) e centraliza (em função de um núcleo de noções mestras)".

\section{Referências}

BARDIN, Laurence. Análise de conteúdo. Lisboa: Edições 70, 1988.

BRASIL. Orientações Curriculares para o ensino médio. Volume 3: Ciências Humanas e suas Tecnologias. Brasília: MEC/SEB, 2006. Disponível em: <http://portal.mec.gov.br>. Acesso em: 30 mai. 2017.

BRASIL. Ciências Humanas e suas Tecnologias. In: BRASIL. Parâmetros Curriculares Nacionais (Ensino Médio): Orientações Educacionais Complementares aos Parâmetros Curriculares Nacionais. Brasília: MEC, 2002. Disponível em: <http://portal.mec.gov.br>. Acesso em: 30 mai. 2017.

BRASIL. $\bigcirc$ novo Ensino Médio. In: BRASIL. Parâmetros Curriculares Nacionais (Ensino Médio. Parte I- Bases Legais). Brasília: MEC, 2000. Disponível em: <http://portal.mec. gov.br>. Acesso em: 30 ago. 2017.

28 BRASIL. Parecer CNE/CEB N $15 / 1998$. In: BRASIL. Parâmetros Curriculares Nacionais (Ensino Médio. Parte I - Bases Legais). Brasília: MEC, 2000a. Disponível em: <http://portal.mec.gov.br>. Acesso em: 30 ago. 2017.

BRASIL. Parecer CNE/CEB N 7/2010. In: BRASIL. Diretrizes Curriculares Nacionais Gerais da Educação Básica. Brasília: MEC, SEB, DICEI, 2013. Disponível em: <http:// portal.mec.gov.br>. Acesso em: 30 ago. 2017.

BRASIL. Resolução N², de 30 de JANEIRO de 2012. Define Diretrizes Curriculares Nacionais para o Ensino Médio. In: BRASIL. Diretrizes Curriculares Nacionais Gerais da Educação Básica. Brasília: MEC, SEB, DICEl, 2013a. Disponível em: <http://portal.mec. gov.br>. Acesso em: 25 ago. 2017.

COLÓQUIO DE VENEZA. A ciência diante das fronteiras do conhecimento, 1; 1986, Veneza: UNESCO - Fundação Giorgio Cini, 1986. Disponível em: <http://cetrans.com. br/declaracao-de-veneza.pdf> Acesso em: 17 mai. 2018.

CONGRESSO INTERNACIONAL DE LOCARNO: Que universidade para o amanhã? Em busca de uma evolução transdisciplinar da universidade, 1; 1997, Locarno. Anais... Locarno: CIRET-UNESCO, 1997. Disponível em: <http://ciret-transdisciplinarity.org/locarno/locapor4. php>. Acesso em: 15 fev. 2018. 
CONGRESSO MUNDIAL DE ARRÁBIDA: Primeiro Congresso Mundial da Transdisciplinaridade, 1; 1994, Arrábida. Anais... Arrábida: CIRET-UNESCO, 1994. (Carta da Transdisciplinaridade). Disponível em: <http://cetrans.com.br/wp-content/uploads/2014/09/carta-da-transdisciplinaridade 1.pdf>. Acesso em: 15 fev. 2018.

DESCARTES, René. Discurso do método. Tradução Jacó Guinsburg e Bento Prado Júnior. São Paulo: Abril Cultural, 1979. (Coleção Os Pensadores).

FERREIRA, João H. Lacerda. Real x Realidade. Portal RedePsi. São Paulo, O6 out. 2008. Disponível em: <http://www.redepsi.com.br/2008/10/06/real-x-realidade/> Acesso em: 13 mar. 2012.

JAPIASSU, Hilton. Interdisciplinaridade e patologia do saber. Rio de Janeiro: Imago, 1976. MARCONI, Marina de Andrade; LAKATOS, Eva Maria. Fundamentos da metodologia científica. São Paulo: Atlas, 2010.

MARINA, José Antônio. Filosofia e cidadania. Tradução Ângela dos Santos e Antón Castro Míguez. São Paulo: Ed. SM, 2010.

MINAYO, Maria Cecília de Souza. O desafio do conhecimento: pesquisa qualitativa em saúde. 7. ed. São Paulo: Hucitec, 2000.

MORIN. Edgar. Ciência com consciência. 8. ed. Tradução Maria D. Alexandre e Maria A. S. Dória. Rio de Janeiro: Bertrand Brasil, 2005.

MORIN. Edgar. Introdução ao Pensamento Complexo. 5. ed. Tradução Dulce Matos. Lisboa: Instituto Piaget, 2008.

MORIN. Edgar. O método 1: a natureza da natureza. 2. ed. Tradução llana Heineberg. Porto Alegre: Sulina, 2008a.

MORIN. Edgar. O método 3: o conhecimento do conhecimento. 3. ed. Tradução Juremir Machado da Silva. Porto Alegre: Sulina, 2005a.

MORIN. Edgar. Os sete saberes necessários à educação do futuro. 2. ed. Tradução Catarina Eleonora F. da Silva e Jeanne Sawaya. São Paulo: Cortez, 2000.

NICOLESCU, Basarab. O manifesto da Transdisciplinaridade. 3. ed. Tradução Lucia Pereira de Souza. São Paulo: Triom, 1999.

NICOLESCU, Basarab. OTerceiro incluído. Da Física Quântica à Ontologia. In: NICOLESCU, Basarab; BADESCU, Horia (Org.). Stéphane Lupasco: o homem e a obra. Tradução Lucia Pereira de Souza. São Paulo: Triom, 2001.

REALE, Giovanni. História da filosofia antiga. Das origens a Sócrates. Tradução Marcelo Perine. São Paulo: Loyola, 1993. 
Artigo

Onsino de filosofia nas perspectivas inter e transdisciplinar: uma análise da problemática ontológica

SILVA, Gilson Malta da. Diário de Campo: notas de aulas de filosofia $-1^{\circ}, 2^{\circ}$ e $3^{\circ}$ anos do Ensino Médio. Colégio Nossa Senhora de Lourdes, Lavras (MG), fev a dez. 2012.

WEIL, Pierre; AMBROSIO, Ubiratan D'; CREMA, Roberto. Rumo à nova transdisciplinaridade: sistemas abertos de conhecimento. São Paulo: Summus, 1993.

Me. Gilson Malta da Silva

Universidade Federal de São João del- Rei (Brasil)

Programa de Pós-Graduação em Processos Sócio-Educativos e Práticas Escolares

E-mail: fidalgogi@hotmail.com; fidalgogi@yahoo.com.br

Recebido 12 jul. 2018

Aceito 19 nov. 2018 